\title{
Low Cost Sausage Preparation from Poultry by- Products and Broiler Meat
}

\author{
O. N. Bhaskar ${ }^{1 *}$,S. Biswas ${ }^{1}$, G. Patra ${ }^{1}$, D. Bhattachraya ${ }^{1}$ and S. Kumari ${ }^{2}$ \\ ${ }^{1}$ Department of Livestock Products Technology, F/O: Veterinary and \\ Animal Sciences, West Bengal University of Animal and Fishery Sciences, 37, \\ K. B. Sarani, Kolkata- 700 037, India \\ ${ }^{2}$ Department Livestock products Technology F/O: Veterinary and Animal Sciences, Bihar \\ Animal Science University, Patna-800014, India \\ *Corresponding author
}

\section{A B S T R A C T}

\section{Keywords}

Chicken sausage, Economics, Poultry by-products, Processing, Binders

Article Info

Accepted:

07 November 2019

Available Online:

10 December 2019
Chicken sausage from poultry by-products were prepared from a standardized formulation and were extended with optimized level of non meat binders viz., sodium caseinate and whole egg powder at $0.5,1.5$ and $2.5 \%$ and 2,4 , and $6 \%$ level respectively. Optimization of levels for extenders was done under different experiments based on sensory attributes and those having sensory status closer to control were selected. The cost of sausage from poultry by- products after replacement of lean with selected level of non meat binders were compared among themselves to determine the most economic preparation. It was found that extended chicken sausage was cheaper than control sausage and among the extended sausage cost was for poultry by- products. The cost for poultry byproducts sausage and binder extended sausage were almost same, but in case of sodium caseinate price were lower than the whole egg powder. In case of poultry by- products (skin, fat, heart and gizzard) were lower in price than extended binder sausage because of higher yield and high level of replacement of lean meat. Thus, it was concluded that formulation accordingly, the net profit per30g sausage was considerable higher in value added experimental product I (By products) followed by II (SC) and III (WEP)

\section{Introduction}

Poultry production in India has taken a quantum jump during two decades despite the threat of avian influenza. Poultry industry is still growing at a much faster rate as compared to other sectors contributing at Rs. 100 billions to the Gross National product (Mohanty and Rajendra, 2003). Poultry meat is considered relatively cheaper and no social taboo is attached to its consumption and hence it is most preferred for developing convenience meat products. Through fresh chicken dominates the Indian market, the consumers 
preference particularly in big cities and metros is shifting in favour of processed products. The increased concern for nutritional security of common mass demands a holistic approach to stretch the availability of quality protein sources by reducing the cost of formulated products.

Comminuted meat products are widely consumed through out of the world but unfortunately its cost especially in the developing countries is not within the reach of middle class non-vegetarian society. Efforts are being made to prepare value added meat based convenience products using low value meat components. It is estimated that during slaughtering of birds, about 10 to $13 \%$ live poultry weight is wasted in the form of skin, gizzard, heart and other by-products (Sharma, 1999). The nutritive value of these edible byproducts in respect of protein and fat is as good as lean meat. It more advisable to incorporate chicken giblet (Heart and gizzard) in the preparation of processed meat products if the consumer is looking for low calorie diet having high protein and polyunsaturated fatty acids.

Effective utilization of these by products for production of value added meat products is one way to realize maximum returns from poultry sector. The ICMR recommendation for protein consumption of $1 \mathrm{~g} / \mathrm{Kg}$ b.wt/day with Net Protein Utilization (NPU) of 65 could be achieved only by introducing the animal proteins in regular diet. Poultry industry, a vibrant, organized and scientific sector now a day in India, can play a key role in ensuring quality animal proteins at cheaper rate, particularly through spent hen meat (FAO, 2006). Processing of meat from spent hen to different "value added products" open the avenues for not only its judicious utilization, but a readily accessible animal protein sources for poor people. Emphasis over food processing and economic formulation has made it necessary to do the needful work in this direction. Reduction of cost by replacement of costly meat with economic non- meaty substances (Huang et al., 2005; Yilmaz and Daglioglu, 2003) has been in practice since long back, but reporting about the actual figure is still inconclusive. At present poultry meat is an important component of human diet particularly in developing countries since it is an affordable source of animal protein for low income class people (Reddy and Qudaratullah, 1996). In general, poultry meat is more acceptable because of its flavour, ease of digestion, low fat content and high ratio of unsaturated fatty acids. Recent studies revealed that apart from supplying essential nutrients, certain bioactive peptides present in meat seen to have distinct physiological health promoting functions. Thus, the present study envisaged to study the actual economization of preparation cost of sausage from poultry by- products after replacement with selected binders at optimum level.

\section{Materials and Methods}

Broiler of approx, 8 wks old were procured from the local market, shyambazar, Kolkata. They were slaughter and dressed according to traditional Halal method. All tendons were removed and separable connective tissue and fat were trimmed off. Dressed meat packed in LDPE pouches was quickly brought to the laboratory, chilled overnight at $41^{\circ} \mathrm{c}$ and then frozen at- $18^{0} \mathrm{C}$ till the experiment. Fresh edible poultry by- products viz. Skin, fat, heart and gizzard were procured from the local meat shop, Kolkata. Gizzard and heart were cleaned for its excess fat. Heart was cut open along its longitudinal section and the clotted blood was removed. Likewise, skin and fat were clean properly, packed in LDPE pouches separately and stored in deep freezer at $-18^{0} \mathrm{C}$ for overnight. After adequate thawing, it was cut into small chunk and minced in meat mincer. 
Minced meat was chopped in bowl chopper for desired duration. The sausage was prepared as per standard method given in flow chart. Cooked chicken sausage was subjected to sensory evaluation and physico- chemical analysis. Sausage batter was stuffed into 20 $\mathrm{mm}$ diameter artificial cellulose casing using mechanical hand stuffer and linked manually. The cooking of sausages in cellulose casing were suspected inside the water bath and cooked for $20 \mathrm{~min}$ at $80^{\circ} \mathrm{C}$ with continuous turning to attain an internal temperature of 70 $\pm 2^{\circ} \mathrm{C}$. After removal from water bath, cold showering was done for $10 \mathrm{~min}$, followed by peeling of casing. Chicken sausage after cooling to room temperature was packed in high density polythene pouches and immediately served to sensory panellists. Overall quality of product made with or without incorporation of poultry by- products and binder was judged on the basis of sensory and physico-chemical characteristics. Cooked chicken sausage was prepared by substituting meat with different levels (10,14 and $18 \%)$ of skin and fat. The best quality product was decided on the basis of sensory and physicochemical characteristics.

Attempts were made to improve the quality of chicken sausage by incorporating different levels of binders viz sodium caseinate (SC) $@ 0.5,1.5$ and $2.5 \%$ and whole egg powder (WEP) @ 2,4 and 6\% level. Meat of the recipe was proportionately replaced with SC and WEP. The product was evaluated for its quality on the basis of different physicochemical characteristics viz., $\mathrm{pH}$, product yield, emulsion stability and proximate composition (moisture, fat and protein content). The product was also subjected to sensory evaluation. The best level of SC and WEP was selected on the basis of above parameters.

\section{Results and Discussion}

The cost of production of one $\mathrm{kg}$ sausage emulsion of control and experimental products is presented in Table 1. The prevailing market rates of different ingredients including boneless meat and edible poultry by- products were considered for calculating the cost. It is observed that the cost per $\mathrm{kg}$ emulsion of control sausage (Rs. 153.65) was higher than the emulsion cost of experimental products.

The emulsion cost was observed to be lowest (Rs. 138.00) in sausage made with incorporation of edible by-products. Further, considering the products yield the cost of production for preparing one $\mathrm{kg}$ sausage was comparatively higher (Rs. 162.78) in control sausage. However, the costs of all the experimental products were almost similar. Since the sausage individually packed in pouches is sold in market, the cost of preparing individual $30 \mathrm{~g}$ sausage was calculated. Accordingly, the net profit per $30 \mathrm{~g}$ sausage was considerably higher in value added experimental product I followed by II and III.

Moreover, it offers better utilization of different types of meat, cuts and edible byproducts. It further facilitates incorporation of low value meat and non- meat ingredients for economy and quality. Milk protein binders such casinate and whey protein concentrate are being used to improve the quality of processed meat. The use of whole egg powder at present is limited. Lot of scope exists to utilize the egg components and protein binders not only to improve the quality but also to lower the cost of processed meat products. Present study thus aimed to develop acceptable value added chicken sausage using low value meat components and binders. 
Table.1 Cost structure of chicken sausage

\begin{tabular}{|c|c|c|c|c|}
\hline Particulars & $\begin{array}{c}\text { Control } \\
\text { sausage }\end{array}$ & $\begin{array}{c}\text { Experimental } \\
\text { product I (By- } \\
\text { products) }\end{array}$ & $\begin{array}{c}\text { Experimental } \\
\text { Product II (SC) }\end{array}$ & $\begin{array}{c}\text { Experimental } \\
\text { powder } \\
\text { III(WEP) }\end{array}$ \\
\hline $\begin{array}{c}\text { Boneless meat * } \\
\text { (Rs) }\end{array}$ & 122.4 & 111.60 & 109.00 & 104.40 \\
\hline $\begin{array}{c}\text { Edible poultry } \\
\text { by- products ** } \\
\text { (Rs) }\end{array}$ & - & 3.40 & 3.40 & 3.40 \\
\hline $\begin{array}{c}\text { Vegetable oil } \\
\text { (Rs) }\end{array}$ & 8.25 & - & - & - \\
\hline $\begin{array}{c}\text { Whole egg } \\
\text { powder (Rs) }\end{array}$ & - & 5.00 & 5.00 & 12.00 \\
\hline $\begin{array}{c}\text { Casing (Rs) } \\
\text { Fuel \& labour } \\
\text { charges (Rs) }\end{array}$ & 10.00 & 10.00 & 10.00 & 5.00 \\
\hline $\begin{array}{c}\text { Other } \\
\text { ingredients } \\
\text { (Spices, } \\
\text { condiments etc) }\end{array}$ & 8.00 & 8.00 & 8.00 & 10.00 \\
\hline $\begin{array}{c}\text { (Rs) } \\
\text { Cost of 1kg } \\
\text { emulsion (Rs) }\end{array}$ & 153.65 & 138.00 & 142.15 & 142.80 \\
\hline $\begin{array}{c}\text { Product yield } \\
\text { (gm) }\end{array}$ & 943.90 & 951.00 & 967.60 & 969.80 \\
\hline $\begin{array}{c}\text { Per kg product } \\
\text { cost (Rs) }\end{array}$ & 192.78 & 145.11 & 146.75 & 147.24 \\
\hline $\begin{array}{c}\text { Cost of 30g } \\
\text { sausage (Rs) }\end{array}$ & 4.88 & 4.35 & 4.40 & 4.42 \\
\hline Net profit (Rs) & 2.62 & 3.15 & 3.10 & 3.08 \\
\hline Bas & & & & \\
\hline
\end{tabular}

Boneless meat @ Rs. 180/kg

Poultry by- products (skin, fat, heart and gizzard) @ Rs. 20/kg

Market price of $30 \mathrm{~g}$ sausage: Rs. 7.50/-

The price of sausage can be lowered with optimum replacement of lean meat by suitable non- meat extenders without a significant compromise with quality. In the study it was also observed that sausage with poultry byproducts extension was cheapest because of higher level of replacement and yield.

\section{Acknowledgement}

The authors are very much thankful to the
Department of Livestock Products Technology, F/O Veterinary and Animal Sciences, West Bengal University of Animal and Fishery Sciences, Kolkata-700037.

\section{References}

Biswas, S., A. Chakraborty, S. Sarkar, R.N. Barpuzari and T. Barpuzari (2007) Effect of incorporation of chicken fat and skin on the quality of chicken 
sausage. J. Poult. Sci., 44(1): 111-115

FAO (2006). http://faostat.fao.org/faostat Production.

Gupta, M (1990) Studies on incorporation of whole egg liquid in mutton and mutton + chicken combination meat sausage. M.V.Sc Thesis, IVRI, Izatnagar, (U.P).

Huang, S.C., Shiau, C.Y., Liu, T.E., Chu, C.L. and Hwang, D.F. (2005). Effects of rice bran on sensory and physicochemical properties of emulsified pork meatballs. Meat Sci., 70:613

Mohanthy, S. And K. Rajenran (2003). 2020 Vision for Indian poultry industry Department of agricultural and applied economics, Texas Tech University,
Lubbook, TX 79409, USA Inter. J. Poult. Sci. 2(2): 139-143.

Reddy, C.V. and S. Qudaratullah (1996). Strategic feeding supplementation through locally available resources, Proceeding of XX World Poultry Congress, New Delhi.

Sharma, B.D. (1999). Meat and meat products technology, $1^{\text {st }}$ edn, Medical publishers (p) limited, New Delhi.

Yilmaz, I. And Daglioglu, O. (2003). The effect of replacing fat with oat bran on fatty acid composition and physicochemical properties of meatballs. Meat Sci., 65:819.

\section{How to cite this article:}

Bhaskar, O. N., S. Biswas, G. Patra, D. Bhattachraya and Kumari, S. 2019. Low Cost Sausage Preparation from Poultry by- Products and Broiler Meat. Int.J.Curr.Microbiol.App.Sci. 8(12): 577-581. doi: https://doi.org/10.20546/ijcmas.2019.812.075 